\title{
MEMBANGUN RESILIENSI : SEBUAH UPAYA \\ PROMOSI KESEHATAN MENTAL DENGAN KERENTANAN DEPRESI
}

\author{
Dian Ratnaningtyas Afifah*
}

\begin{abstract}
Abstrak
Sehat adalah dambaan setiap orang. Kondisi sehat bukan sekedar terbebas dari kecacatan, penyakit ataupun kelemahan, namun sehat lebih melibatkan pada kondisi "psychological well being" (kesejahteraan psikologis).

Seiring kemajuan zaman, perubahan-perubahan yang terjadi berlangsung sangat cepat, tidak jarang menimbulkan berbagai dampak yang tidak menyenangkan bagi individu. Hal itu menyebabkan terhambatnya dalam mencapai kondisi psychological well being, sehingga tidak sedikit orang yang hidup di era modern mengalami gangguan psikologis seperti stress, perilaku adiktif bahkan depresi yang umumnya mengarahkan pada tindakan percobaan bunuh diri. Oleh sebab itu, dibutuhkan suatu ketahanan psikologis (resiliensi) untuk menghadapi segala persoalan hidup, yakni situasi atau peristiwa yang menekan. Dengan kemampuan resiliensi, diharapkan mampu meminimalisir dan mencegah adanya gangguan psikologis depresi.
\end{abstract}

Kata kunci : Resiliensi, Promosi Kesehatan Mental, Kerentanan Depresi

* Dian Ratnaningtyas Afifah adalah Dosen Bimbingan dan Konseling IKIP PGRI Madiun 


\section{A. Pendahuluan}

Dengan kemajuan zaman problem-problem pribadi dan sosial pada manusia bukan semakin berkurang, tetapi sebaliknya, bahkan bertambah sehingga mengganggu untuk mencapai kebahagian hidup yang diidamidamkan. Pengaruh lingkungan (sosial, ekonomi, politik, ekologi, iklim dan lainnya) terhadap kesejahteraan psikologis dari suatu populasi sangatlah kompleks dan beragam. Pergolakan ekonomi (inflasi dan sebagainya), perilaku anti sosial (perampokan, pemerkosaan, penganiayaan dan sebagainya), ketidakserasian penerapan hukum dan peraturan, kehidupan berkeluarga yang bermasalah (percekcokan, kekerasan dalam keluarga, perceraian dan sebagainya), kesulitan atau ketidakmampuan menjalankan nilai-nilai sosial kultural semua bertumpuk-tumpuk memicu konflik dan stres. Situasi tersebut menimbulkan kondisi maladujstment (keadaaan ketidaksesuaian diri dengan lingkungan), yang dinyatakan secara jasmaniah (seperti kondisi sakit atau kurang sehat sehingga terpaksa tidak masuk kerja) ataupun memunculkan perilaku yang menyimpang hingga kurang diterima oleh lingkungan karena dinilai tidak wajar.

Kondisi-kondisi dalam kemajuan era modern tak pelak membawa perubahan yang sangat cepat. Perubahan-perubahan yang cepat tersebut tidak jarang menimbulkan dampak yang tidak menyenangkan berupa tekanan bagi individu. Salah satu dampak atas perubahan tersebut adalah depresi.

Depresi merupakan gangguan mental yang umum dijumpai hampir diseluruh dunia. Berbagai keluhan fisik yang dialami seseorang kemungkinan merupakan akibat depresi. Sayangnya hal itu jarang disadari, penderita umumnya datang ke dokter dengan keluhan kelelahan, insomnia, nyeri kepala, gejala sakit maag atau gejala fisik yang lain. Peristiwa kehidupan yang penuh tekanan seperti kehilangan orang yang dicintai, putusnya hubungan romantis, lamanya hidup menganggur, sakit fisik, masalah dalam pekerjaan dan perkawinan, meningkatkan resiko berkembangnya gangguan mood atau kambuhnya gangguan mood, terutama depresi mayor (Nevid dkk, 2005).

Untuk menghadapi kondisi-kondisi yang tidak menyenangkan dan menekan terserbut, sejumlah ahli psikologi memandang perlu untuk 
membangun kekuatan individu. Dalam hal ini resiliensi dianggap sebagai kekuatan dasar yang menjadi fondasi dari semua karakter positif dalam membangun kekuatan emosional dan psikologikal seseorang. Tanpa adanya resiliensi, tidak akan ada keberanian, ketekunan, tidak ada rasionalitas, tidak ada insight (Desmita, 2005).

\section{B. Pembahasan}

\section{Pengertian Resiliensi}

Resiliency jika diterjemahkan ke dalam bahasa Indonesia lebih kurang mirip artinya dengan kekenyalan, keuletan, atau ketangguhan. Dalam konteks psikologi, kata resiliency ini sering dikaitkan dengan isitilah hardiness (hard $=$ keras), dan resiliency dipandang sebagai faktor penting bagi seseorang untuk mampu bertahan hidup dalam situasi sesulit apapun.

Henderson \& Milstein (2003) mengungkapkan bahwa resiliensi adalah kemampuan seseorang untuk bangkit kembali dari tekanan hidup, belajar dan mencari element positif dari lingkungannya, untuk membantu kesuksesan proses beradaptasi dengan segala keadaan dan mengembangkan seluruh kemampuannya, walau berada dalam kondisi hidup tertekan, baik secara eksternal atau internal.

Sementara itu menurut Emmy E. Werner (2003 dalam Desmita, 2005 : 227), sejumlah ahli tingkah laku menggunakan istilah resiliensi untuk menggambarkan tiga fenomena : (1) perkembangan positif yang dihasilkan oleh anak yang hidup dalam konteks "beresiko tinggi" (high risk), seperti anak yang hidup dalam kemiskinan kronis atau perlakuan kasar orang; (2) kompetensi yang dimungkinkan muncul dibawah tekanan yang berkepanjangan, seperti peristiwa-peristiwa di sekitar perceraian orang tua; dan (3) kesembuhan dari trauma seperti ketakutan dari peristiwa perang saudara dan kamp konsentrasi. Untuk dapat berkembangn secara positif atau sembuh dari kondisi-kondisi stres, trauma dan penuh resiko tersebut, manusia membutuhkan keterampilan resiliensi, yang meliputi (1) kecakapan untuk membentuk hubungan-hubungan (kompetensi sosial), (2) keterampilan 
memecahkan masalah (metakognitif), (3) keterampilan mengembangkan sense of identity (otonomi) dan (4) perencanaan dan pengharapan (pemahaman tentang tujuan dan masa depan). Untuk lebih jelasnya, Desmita (2005) mengutip beberapa definisi resiliensi dari sejumlah ahli, diantaranya: Resilience is the human capacity to face, overcome, be strengthened by and even be transformed by experiences of adversity (Grotberg, 1999).

Resiliency is the ability to bounce back successfully despite exposure to severe risk. A resilience comunity is community focused on the protective factors that foster resiliency for its members: (1) caring; (2) high expectations and purposeful support, and (3) ongoing opportunities for mainingful participation (Benard, dalam Krovetz).

Resilience can be defined as the capacity to spring back, rebound, successfully adapt in the face or adversity, and develop social, academi, and vocational competence despite exposure to severe stress or simply to the stress that is inherent in today's world (Werner, 2003).

Dari beberapa definisi diatas dapat dipahami bahwa resiliensi adalah kemampuan atau kapasitas yang dimiliki oleh seseorang, kelompok atau masyarakat yang memungkinkannya menghadapi, mencegah, meminimalkan dan bahkan menghilangkan dampak-dampak yang merugikan dari kondisi-kondisi yang tidak menyenangkan atau bahkan mengubah kondisi kehidupan yang menyengsarakan menjadi suatu hal yang wajar untuk diatasi.

Lebih lanjut Desmita (2005) mengungkapkan bahwa resiliensi adalah suatu kemampuan yang sangat dibutuhkan dalam kehidupan setiap orang. Hal ini karena kehidupan manusia senantiasa diwarnai oleh adversity (kondisi yang tidak menyenangkan). Adversity menantang kemampuan manusia untuk mengatasinya, untuk belajar darinya dan bahkan untuk berubah karenanya. 


\section{Faktor-faktor yang Mempengaruhi Resiliensi}

Dalam rangka mengatasi kondisi-kondisi adversity dan mengembangkan resiliensi, sangat tergantung pada pemberdayaan tiga faktor dalam diri seseorang. Grotberg (dalam Desmita, 2005) mengungkapkan tiga sumber resiliensi (three source of resilience) yaitu $I$ have (Aku punya), I am (Aku ini) dan I can (Aku dapat).

I have (Aku Punya) merupakan sumber resiliensi yang berhubungan dengan pemaknaan terhadap besarnya dukungan yang diberikan oleh lingkungna sosaol terhadap dirinya. Sumber I have ini memiliki beberapa kualitas yang memberikan sumbangan bagi pembentukan resiliensi yaitu :

a) Hubungan yang dilandasi oleh kepercayaan penuh;

b) Stuktur dan peraturan di rumah;

c) Model-model peran;

d) Dorongan untuk mandiri (otonomi);

e) Akses terhadap layanan kesehatan, pendidikan, keamanan dan kesejahteraan.

I am ( Aku ini) merupakan sumber resiliensi yang berkaitan dengan kekuatan pribadi yang dimiliki, terdiri dari perasaan, sikap dan keyakinan pribadi. Beberapa kualitas pribadi yang mempengaruhi I am adalah :

a) Disayang dan disukai oleh banyak orang;

b) Mencinta, empati dan kepedulian pada orang lain;

c) Bangga dengan diri sendiri;

d) Bertanggung jawab terhadap perilaku sendiri dan menerima konsekuensinya;

e) Percaya diri, optimistik dan penuh harap.

I can (Aku dapat) adalah sumber resiliensi yang berkaitan dengan apa saja yang dapat dilakukan sehubungan dengan keterampilanketerampilan sosial dan interpersonal. Keterampilan-keterampilan ini meliputi :

a) Berkomunikasi;

b) Memecahkan masalah;

c) Mengelola perasaan dan impuls-impuls; 
d) Mengukur temperamen sendiri dan orang lain;

e) Menjalin hubungan-hubungan yang saling mempercayai.

Dari uraian di atas, dapat disimpulkan terdapat dua faktor yang mempengaruhi pembentukan resiliensi yaitu faktor internal atau dari dalam individu sendiri dan faktor eksternal atau faktor-faktor dari luar individu. Hal ini diperkuat pendapat Milstein dan Henry (dalam Jones 2003:2-3) yang menegaskan bahwa terdapat dua faktor-faktor yang mempengaruhi resiliensi terdiri dari dua faktor yaitu faktor internal dan faktor eksternal diantaranya :

Faktor internal yakni kemampuan internal yang dimiliki individu untuk meningkatkan resiliensi meliputi :

a) Memberikan kesempatan pada diri kita untuk melayani orang lain.

b) Menggunakan kemampuan hidup dengan membuat keputusan yang baik,sikap yang tegas, mengontrol impuls dan menyelesaikan masalah.

c) Suka bergaul dan mampu menjadi teman dari hubungan yang positif.

d) Memiliki rasa humor

e) Percaya pada kemampaun terhadap pengaruh lingkungan disekitarnya.

f) Kesadaran dan kebebasan.

g) Memiliki pandangan yang positif terhadap seseorang dimasa yang akan datang.

h) Sikap yang fleksibel

i) Memiliki spiritual dan percaya dengan kekuatan yang tinggi.

j) Dapat mengerti saat belajar

k) Memiliki motivasi dalam hidup.

1) Memiliki pandangan yang baik terhadap kompetensi dengan seseorang.

m) Memilki perasaan berharga dan percaya terhadap dirinya.

Faktor eksternal yaitu kemampuan diluar diri seseorang, seperti keluarga, sekolah, masyarakat dan teman sebaya, hal itu dapat mengembangkan resiliensi ketika mereka mempunyai faktor-faktor eksternal tersebut. Beberapa faktor eksternal yang mempengaruhi antara lain : 
a) Nilai dan dorongan pendidikan.

b) Mengembangkan ikatan persahabatan

c) Menggunakan kehangatan yang tinggi dan mengurangi gaya mengkritisi dalam berinteraksi

d) Menetapkan dan menjalankan batas yang jelas.

e) Membina hubungan yang mendukung dengan memberikan banyak perhatian pada orang dewasa.

f) Mengembangkan melayani orang lain..

g) Menyediakan jalan (sarana) sebagai sumber daya untuk melakukan pertemuan tentang dasar-dasar kebutuhan rumah tangga, pekerjaan, kesehatan dan rekreasi.

h) Mengekpresikan harapan yang tinggi dan realistis untuk sukses.

i) Dorongan untuk mengatur cita-cita dan penguasaanya.

j) Mendorong perkembangan nilai prososial dan ketrampilan hidup.

k) Melengkapi dengan kepemimpinan, membuat keputusan dan kesempatan yang lain untuk keikutsertaan yang bermakna.

1) Menghargai bakat atau kemampuan yang unik (khusus) pada setiap individu

\section{Karakteristik Resiliensi}

Terdapat karakteristik-karateristik tertentu bagi orang yang resilien, sebagaimana dicirikan dalam The road to resilience (2004). Karakteritik orang yang resilien meliputi :

a) Kemampuan untuk "bangkit kembali"

b) Mempunyai sikap “ dimana ada kemauan, disitu ada jalan” (where there's a will, there's a way)

c) Cenderung melihat masalah sebagai suatu kesempatan.

d) Kapasitas untuk melihat jendela kecil dari kesempatan dan membuat lebih besar dari mereka.

e) Mempunyai sumber kepercayaan (keimanan) yang tinggi pada takdir.

f) Mempunyai dukungan jaringan kerja yang sehat.

g) Mempunyai daerah kenyamanan yang luas. 
h) Mampu untuk menemukan kembali dari pengalaman dalam keadaan panik dan alam traumatis.

Kemudian Darryl Conner (tanpa tahun) dalam bukunya "Managing at the Speed of Change" membuat daftar lima karakteristik dari resiliensi yaitu :

a) Be Positive

b) Melihat hidup sebagai tantangan, dinamis dan diisi dengan berbagai kesempatan

c) Be Focused

d) Memutuskan dimana kamu akan diarahkan dan menancap kecita-cita sehingga rintangan itu tidak akan menghalangi jalanmu.

e) Be Flexible

f) Buka dirimu untuk melihat perbedaan kemungkinan ketika menghadapi ketidakpastian.

g) Be Organized

h) Mengembangkan pendekatan terstruktur untuk mampu mengatur ketidaktahuan.

i) Be Proactive

j) Lihat kedepan, aktiflah menggunakan perubahan dan bekerjalah dengan perubahan itu.

\section{Depresi}

Depresi merupakan sebuah gangguan psikologis yang banyak terjadi di era modern ini. Dalam sebuah acara peringatan Hari Kesehatan Jiwa Sedunia disampaikan data WHO yang memperkirakan 121 juta orang kini menderita depresi : $5.8 \%$ pria dan 9,5\% wanita mengalami episode depresi pada tahun tertentu. diperkirakan depresi akan menempati peringkat ke 2 dari penyebab utama kecacatan, setelah penyakit janting pada tahun 2020 .

Sehubungan dengan tingginya tingkat kejadian depresi, gangguan yang berhubungan dengan alam perasaan (mood) ini perlu mendapat perhatian. Salah satu penyebab perlunya perhatian terhadap depresi adalah 
depresi merupakan gangguan jiwa yang paling berhubungan dengan terjadinya bunuh diri. Hal ini ditegaskan oleh Beck (dalam Corsini, 2000 : 250) mengatakan bahwa individu yang mengalami depresi mempunyai pandangan negatif tentang dirinya, dunia sekitar dan masa depannya, serta melihat dirinya sebagai seseorang yang tidak mampu, hampa dan tidak berharga. Pribadi yang mengalami depresi berfikir dengan cara-cara yang negatif dan aneh tentang dirinya sendiri, lingkungan dan masa depannya. Kondisi mental pesimistik tersebut mempengaruhi suasana hatinya, motivasi dan hubungannya dengan orang lain serta menyebabkan timbulnya berbagai gejala psikologis dan fisik yang khas (Burns, 1980: 1). Adanya sikap menyerah atas masalahnya mungkin akan mendorong seseorang memiliki pemikiran untuk melakukan bunuh diri (Corsini, 2000 :251).

\section{Penutup}

Mood adalah kondisi perasaan yang terus ada untuk mewarnai kehidupan psikologis manusia. Perasaan sedih atau depresi bukanlah hal yang abnormal saat mengalami suatu peristiwa atau situasi yang menekan dalam kehidupan, seperti perceraian, kematian, permasalahan ekonomi bahkan persaiangan. Namun akan menjadi sebuah gangguan atau abnormalitas jika seseorang mengalami gangguan mood yang luar biasa parah, berlangsung dalam waktu lama dan mengganggu kemampuannya untuk berfungsi dan memenuhi tanggung personal maupun sosial secara normal.

Supaya individu mampu menyesuaikan diri, bertahan dan bersikap positif saat dihadapkan pada situasi yang menekan, dibutuhkan kemampuan resiliensi untuk bangkit kembali sehingga dapat meminimalisir dan mencegah munculnya depresi. Untuk mengembangkan kemampuan resiliensi, seseorang diharapkan mampu mengenali sumberdaya bagi pembentukan sikap resilien, diantaranya (1) memaknai besarnya dukungan sosial yang diberikan lingkungan terhadap dirinya; (2) memiliki kualitas pribadi seperti empati, percaya diri, optimistik dan bertanggung jawab terhadap diri sendiri; dan (3) 
memiliki keterampilan sosial dalam berkomunikasi, baik intrapersonal maupun interpersonal.

\section{Daftar Pustaka}

Burns, David D. 1980. Terapi Kognitif. Pendekatakan Baru Bagi Penanganan Depresi. Jakarta : Erlangga

Corsini, J Raymond \& Danny Wedding. 2000. Curent Psychotherapist. Sixth Edition. Itasca Illinois USA : Peacocks Publisher

Desmita. 2009. Psikologi Perkembangan Peserta Didik. Bandung : Remaja Rosda Karya

Jones, Jami L. tanpa tahun. Resiliency High: A Blueprint for Resiliency-Based Education

Kusmanto Setyonegoro. 2005. Kesehatan Jiwa (Mental Health) di Kehidupan Modern. Jurnal Cermin Dunia Kedokteran No.149

Nevid.J.S, Spencer A. Rathus, Beverly Greene. 2005. Psikologi Abnormal. Jilid I.Terjemahan.Jakarta:Penerbit Erlangga. 